\title{
ORIENTASI PASAR DAN INOVASI PRODUK PENGARUHNYA TERHADAP KEUNGGULAN BERSAING (Studi Pada UMKM Tenun Gedogan Kota Bima)
}

\author{
Muhajirin', Kamaluddin ${ }^{2}$ \\ 1Program Studi Manajemen.E-mail: jirin.stiebima@gmail.com \\ 2Sekolah Tinggi Ilmu Ekonomi (STIE) Bima
}

\begin{abstract}
ARTICLE INFO
Keywords :

Market Orientation, Product Innovation, Competitive Advantage

How to cite :

Muhajirin., Kamaluddin., (2019). Orientasi Pasar dan Inovasi Produk Pengaruhnya Terhadap Keunggulan bersaing (Studi Pada UMKM Tenun Gedogan Kota Bima). JMM UNRAM, 8(4), 407-418
\end{abstract}

DOI :

http://dx.doi.org/10.29303/jmm.v8i4.474

$\begin{array}{ll}\text { Dikumpulkan } & : 22 \text { Agustus } 2019 \\ \text { Direvisi } & : 29 \text { Agustus } 2019 \\ \text { Dipublikasi } & : \text { :03 September } 2019\end{array}$

\begin{abstract}
Small and medium enterprises are one of the leading drivers in the world economic development. Small and medium enterprises are one of the fields in absorption very significant workforce. At this time is a period of globalization where competition is getting tougher, many companies will go bankrupt or out of business if the company does not prepare the company inside current competition. The goal to be achieved is to increase market orientation and product innovation towards competitive advantage in the Gedong Weaving Small and medium enterprises (UMKM) in the City of Bima. The data used is primary data. Research sample amounting to 90 respondents. The data analysis tool in this study uses multiple linear regression. The results of this study indicate that Market orientation positive and significant effect on competitive advantage in UMKM Weaving Gedogan in Bima City, product orientation has a positive and significant effect on competitive advantage in Gedogan Weaving Small and medium enterprises (UMKM) in Bima City and there are the positive and significant influence of market orientation and product innovation has been reduced Competitive advantage in UMKM Weaving in Bima City. So that it is higher market orientation is carried out, and the higher the level of product innovation, then Increasing competitive advantage in Gedogan Weaving Small and medium enterprises (UMKM) in Bima City.

Usaha kecil menengah merupakan salah satu pendorong terdepan dalam perkembangan ekonomi. UMKM merupakan salah satu bidang dalam penyerapan tenaga kerja yang sangat signifikan. Pada saat ini merupakan masa globalisasi yang dimana persaingan sudah semakin ketat, banyak perusahaan yang akan bangkrut atau gulung tikar apabila perusahaan tidak mempersiapkan perusahaan dalam persaingan saat ini. Tujuan yang ingin dicapai adalah peningkatan orientasi pasar dan inovasi prodak terhadap keungulan bersaing pada UMKM Tenun
\end{abstract}




\section{Jurnal Magister Manajemen Unram Vol. 8, No 4. November 2019 NATIONALLY ACCREDITED JOURNAL - DECREE NO. 21/E/KPT/2018}

Gedong yang ada di Kota Bima. Data yang digunkan adalah data primer. Sampel penelitian berjumlah 90 Responden. Alat analisis data dalam penelitian ini menggunakan regresi linear berganda. Hasil penelitian ini menujukan bahwa Orientasi Pasar berpengaruh positif dan signifikan terhadap keunggulan bersaing pada UMKM Tenun Gedogan di Kota Bima, Orientasi produkberpengaruh positif dan signifikan terhadap keunggulan bersaing pada UMKM Tenun Gedogan di Kota Bima dan terdapat pengaruh positif dan signifikan orientasi pasar dan inovasi produk terdahap keunggulan besaing pada UMKMTenun di Kota Bima. Sehingga semakin tinggi orientasi pasar yang dilakukan, serta semakin tinggi tingkat inovasi produk, maka semakin meningkat keunggulan bersaing pada UMKM Tenun Gedogan di Kota Bima. Copyringht @ 2019 JMM UNRAM. All ringhts reserved

\section{PENDAHULUAN}

Saat ini kondisi persaingan di sektor UMKM mulai cukup ketat dan kompleks, sudah banyak sekali UMKM yang berkembang hingga maju di berbagai kepulauan Indonesia, salah satunya merupakan usaha yang bergerak dalam bisnis konveksi tenun. Usaha tenun yang sudah cukup lama berkembang di Nusa Tenggara Barat ialah produk UMKM tenun yang terletak di kota Bima.

Menurut hasil survei lapangan secara langsung oleh Dinas Koperasi \& UMKM, diperkirakan perkembangan UMKM tenun perlahan-lahan mulai mengalami peningkatan yang cukup baik, namun di tahun-tahun ini berikutnya mulai mengalami penurunan sedikit demi sedikit dikarenakan kurangnya perhatian pelaku usaha tenun dalam menghasilkan produk yang unggul dibandingkan dengan hasil produk tenun dari luar Kota Bima.

Di Kota Bima, produk khas yang menjadi andalan bagi UMKM sendiri bermacam macam, salah satunya adalah produk tenunan. Pembuatan produk ini terbilang masih tradisonal karena belum terlalu banyak menggunakan peralatan canggih sehingga volume produksinya pun terbatas. Walaupun terbilang produk yang memiliki ciri khas tersendiri, persaingan untuk memenuhi kebutuhan pelanggan akan tenunan inipun tidak bisa dihindari hal ini disebabkan oleh orientasi pasar yang diterapkan oleh setiap UMKM masih homogen dan tidak terarah dimana UMKM hanya sebatas memproduksi berdasarkan kebiasaannya saja tanpa mencari informasi akan harapan konsumen dan tidak menggali informasi tentang pesaing. Disamping itu, inovasi dari produk UMKM tenun di Kota Bima ini terbilang masih sederhana dan minim sehingga produk tenunan antara UMKM yang satu dengan UMKM yang lain masih serupa dan tidak ditemukan perbedaan yang mecolok sehingga terjadi persaingan yang ketat antar UMKM. Memahami kepuasan pelanggan sangat diperlukan dan mengenali pergerakan para pesaing dipasar perlu ditingkatkan yaitu dengan cara berorientasi terhadap pasar. Orientasi pasar merupakan sebuah strategi atau budaya yang dapat digunakan sebagai sumber untuk meningkatkan kinerja pemasaran produk terutama tenun yang saat ini mengalami kondisi persaingan yang sangat ketat. Dalam lingkungan persaingan yang tinggi, hanya perusahaan yang mempunyai nilai lebih yang akan sanggup bertahan (Parengki Susanto, 2012).

Perusahaan yang berorentasi terhadap pasar akan senantiasa melakukan efisiensi dan selalu berusaha menciptakan nilai lebih bagi pelanggannya yang diharapkan akan dapat 


\section{Jurnal Magister Manajemen Unram Vol. 8, No 4. November 2019 NATIONALLY ACCREDITED JOURNAL - DECREE NO. 21/E/KPT/2018}

menciptakan keunggulan bersaing serta memberikan keuntungan jangka panjang bagi perusahaan. Pentingnya orientasi terhadap pasar sangat berkaitan dengan hasil produk yang ditawarkan kepada pelanggan. Produk yang dihasilkan harus menarik dan memiliki keunikan agar dapat unggul dalam persaingan.

Kemampuan UMKM Tenun untuk bertahan dan maju sepenuhnya tergantung dari kemampuan UMKM untuk menciptakan dan menumbuhkan daya saing, serta mampu menyesuaikan diri dengan perubahan lingkungan yang terjadi. Dapat dilihat pada era sekarang ini, persaingan yang tinggi tidak hanya dirasakan oleh perusahaan-perusahaan besar, perusahaan menengah seperti tenun juga mengalami persaingan yang amat ketat. Kemajuan perusahaan di industri tenun sepenuhnya tergantung dari kemampuan perusahaan untuk menciptakan dan menumbuhkan daya saing yang dapat menyesuaikan diri dengan cepat terhadap perubahan yang terjadi. Tujuan yang ingin dicapai adalah peningkatan orientasi pasar dan inovasi prodak terhadap keungulan bersaing pada UMKM Tenun Gedong yang ada di Kota Bima.

\section{TINJAUANPUSTAKA}

\subsection{Orientasi Pasar}

Orientasi pasar merupakan suatu perspektif bisnis yang membuat pelanggan sebagai titik pusat pandangan atas operasi perusahaan secara menyeluruh: Pada dasarnya perusahaan haruslah berorientasi pada pasar, sehingga dibutuhkannya budaya yang secara sistematik dan menyeluruh untuk berkomitmen secara berkelanjutan bagi penciptaan sebuah keunggulan bersaing, dan pencapaian orientasi pasar haruslah dapat mencakup penggunaan keterampilan atau skills pengorganisasian yang superior, terutama dalam memahami dan memuaskan pelanggan, dimana untuk dapat memenuhi rumusan orientasi pasar, dibutuhkan upaya untuk mengumpukan informasi tentang pelanggan, para pesaing dan pasar, dan dengan orientasi pasar, suatu perusahaan haruslah mampu secara berkelanjutan memantau perubahan kebutuhan dan keinginan pelanggan dengan cepat dan tepat (Sofian Assauri, 2012).

Orientasi pasar dapat diartikan sebagai implementasi budaya organisasi yang menempatkan pelanggan pada poros dari proses strategi manajemen perusahaan. Integrasi antar fungsi dalam organisasi memerlukan sumberdaya, khususnya pengetahuan dan keahlian dari setiap pekerja sehingga dapat mendukung organisasi dalam menyajikan nilai terbaik bagi pelanggannya. Indikator Yang Mempengaruhi Orientasi Pasar : a). Orientasi pelanggan yaitu kemauan perusahaan untuk memahami kebutuhan dan keinginan para pelangganya, b). Orientasi pesaing adalah kemauan perusahaan untuk memonitor strategi yang diterapkan para pesaingnya dan c). Informasi pasar adalah upaya perusahaan untuk mencari informasi tentang kondisi pasar industri. (Pramesti dan Giantari, 2016).

\subsection{Invovasi Produk}

Produk inovasi pada dasarnya adalah untuk memenuhi permintaan pasar sehingga produk inovasi merupakan salah satu yang digunakan sebagai keunggulan bersaing bagi perusahaan. Inovasi menciptakan gagasan baru dan menjalankan dalam prakteknya. Inovasi merupakan ide-ide baru dalam produk, sehingga hasilnya lebih baik. Dalam organisasi perusahaan inovasi dalam dua bentuk yaitu : Inovasi produk, yang menghasilkan barang atau jasa baru atau perbaikan dari yang telah ada dan Inovasi proses, yeng menghasilkan cara baru dalam mengerjakan sesuatu proses. (Adelina,et.al, 2016).

Inovasi adalah suatu ide, gagasan, praktek atau objek/benda yang disadari dan diterima sebagai suatu hal yang baru oleh seseorang atau kelompok untuk diadopsi. 


\section{Jurnal Magister Manajemen Unram Vol. 8, No 4. November 2019 NATIONALLY ACCREDITED JOURNAL - DECREE NO. 21/E/KPT/2018}

Inovasi juga dapat diartikan sebagai pemikiran kreatif individu yang dapat menghasilkan ide bagi perusahaan (Robbins dan Mary, 2010). Inovasi produk menciptakan kwalitas dengan berbeda dan dapat diterima konsumen sehingga mampu memberikan kepuasan konsumen (Robbins dan Mary, 2010). Adapun Indikator inovasi produk dibagi menjadi tiga yaitu: yaitu Perluasan Produk, peniruan produk, produk baru (Cynthia dan Hendra, 2014)

\subsection{Keunggulan Bersaing}

Dengan memiliki Keunggulan bersaing maka perusahaan akan mampu bertahan untuk melanjutkan hidup perusahaan. Keunggulan bersaing mutlak harus dimiliki oleh perusahaan/produk untuk mencapai kinerja atau sukses produk yang dihasilkan. (Ekawati, et, al, 2016)

Keunggulan bersaing diharapkan mampu untuk mencapai laba sesuai rencana, meningkatkan pangsa pasar, meningkatkan kepuasan pelanggan, serta melanjutkan kelangsungan hidup suatu usaha (Hair, et, al, 2010). Keunggulan bersaing ada tiga indikator yang digunakan dalam pengukur keunggulan bersaing adalah sebagai berikut : Keunggulan diferensiasi produk, keunggulan segmentasi pasar dan Keunggulan memasuki pasar. (Kotler and Armstrong, 2012).

Li dalam Jayaningrum (2018), bahwa keunggulan bersaing dapat diperoleh dari kemampuan perusahaan untuk mengolah dan memanfaatkan sumber daya dan modal yang dimilikinya. Produsen yang mampu menciptakan keunggulan bersaing akan memiliki kekuatan untuk bersaing dalam perusahaan lainnya karena produknya akan diminati oleh pelanggan.

\subsection{Tinjauan Penelitian Terdahulu}

Akhmad Supriyanto, et., al. (2017), meneliti pengaruh orientasi pasar dan inovasi produk terhadap keunggulan bersaing (studi pada UMKM kopiah haji di kabupaten hulu sungai tengah). Hasil penelitian menunjukan bahwa pengaruh orientasi pasar secara parsialberpengaruh positif dan signifikan terhadap keunggulan bersaing dan inovasi produk secara parsial berpengaruh positif dan signifikan terhadap keunggulan bersaing. Sehingga semakin tinggi orientasi pasar yang dilakukan, serta semakin tinggi tingkat inovasi produk, maka semakin meningkat keunggulan bersaing UMKM kopiah haji di kabupaten Hulu Sungai Tengah.

Niken Wahyu, (2017), meneliti pengaruh keunggulan bersaing dan inovasi produk dengan kinerja pemasaran pada usaha batik tegala di kabupaten tegal. Hasil pengujian statistik menunjukkan bahwa secara parsial inovasi produk berpengaruh positif terhadap kinera pemasaran sebesar $67,7 \%$ dan keunggulan bersaing berpengaruh positif terhadap kinerja pemasaran sebesar $68,5 \%$. Kemudian hasil pengujian secara simultan menunjukkan bahwa variable inovasi produk dan keunggulan bersaing berpengaruh sebesar 77,7 \%terhadap kinerja pemasaran. Namun variabel keunggulan bersaing yang paling berpengaruh terhadap kinerja pemasaran sebesar 68,5 persen.Hasil uji koefisien determinasi menunjukkan besarnya kinerja pemasaran yang dapat dijelaskan oleh variabel iovasi produk dan keunggulan bersaing sebesar60,4 \% dan sisanya sebanyak 39,4\% dipengaruhi oleh factor lain yang tidak dapatdijelaskan.

Aristin Nikmah, et., al. (2016), meneliti pengaruh orientasi pasar, orientasi pembelajaran dan inovasi produk terhadap keunggulan bersaing IKM (sentra IKM tenun ikat torso kabupaten jepara). Hasil penelitian menunjukkan bahwa variabel orientasi pembelajaran, orientasi pasar dan inovasi produk memiliki pengaruh yang positif dan signifikan terhadap keunggulan bersaing, secara parsial sebesar 30\%, 28\% dan 28,9\% 


\section{Jurnal Magister Manajemen Unram Vol. 8, No 4. November 2019 NATIONALLY ACCREDITED JOURNAL - DECREE NO. 21/E/KPT/2018}

sedangkan secara simultan sebesar 31,5\%. Berdasarkan kesimpulan tersebut maka pemilik IKM perlu memperhatikan hal-hal mengenai komitmen terhadap pembelajaran, orientasi terhadap pelanggan, penciptaan produk baru dan keunikan produk, karena hal tersebut memiliki rata-rata terendah.

\subsection{Kerangka Konseptual}

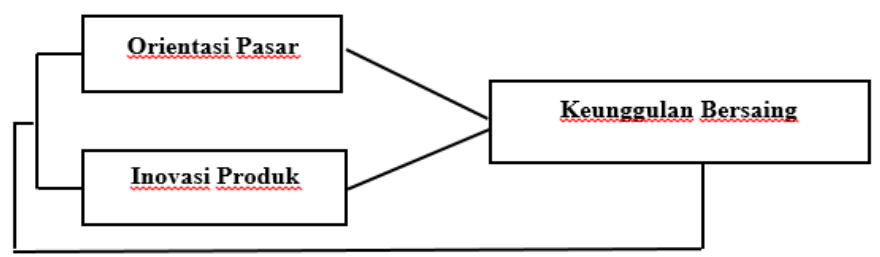

Berdasarkan konsep penelitian, maka hipotesis penelitian adalah sebagai berikut:

$\mathrm{H}=$ Orientasi Pasar pengaruh positif dan singnifikan secara parsial terhadap keunggulan bersaing pada UMKM Tenun Gedogan di Kota Bima.

$\mathrm{H} 2=$ Inovasi Produk pengaruh positif dan singnifikan secara parsial terhadap keunggulan bersaing pada UMKM Tenun Gedogan di Kota Bima.

H3 = Orientasi Pasar dan Inovasi Produk pengaruh positif dan signifikan secara simultan terhadap keunggulan bersaing pada UMKM Tenun Gedogan di Kota Bima

\section{METODE PENELITIAN}

Lokasi Penelitian dilakukan di Kota Bima. Penelitian dilakukan bulan April sampai Juni 2019. Jenis penelitian yang digunakan dalam penelitian ini adalah menggunakan penelitian asosiatif. Jenis data yang digunakan adalah data kuantitatif dengan tiga Variable yaitu Orientasi Pasar, Inovasi Produk dan Keunggulan Bersaing. Sumber data menggunakan data primer dan dikumpulkan secara langsung dengan menggunakan kuisioner (angket). Populasi dalam penelitian ini adalah seluruh pemilik dan pengelola UMKM tenun gedogan yang terdaftar di Dinas Koperasi \& UMKM Kota Bima yang berjumlah 1.534 UMKM. Jumlah sampel yang representatif adalah tergantung jumlah indikator dikalikan 5 sampai 10. (Hair, et, al, 2010). Jumlah sampel = jumlah indikator (9) $x$ $10=90$ Responden. Dengan mengacu pada perhitungan jumlah minimal sampel dan pertimbangan jumlah populasi yang ada, maka jumlah sampel yang dipilih adalah sebanyak 90 responden. Teknik sampling yang digunakan adalah teknik purposive samplingyaitu pengambilan anggota sampel dari populasi yang dilakukan secara acak, tanpa memperhatikan stratanya. Alat analisis data dalam penelitian ini menggunakan regresi linear berganda dengan bantuan SPSS versi 20 for windows.

\section{HASIL PENELITIAN DAN PEMBAHASAN}

\subsection{Deskripsi Data Hasil Penelitian}

Penelitian ini mengambil sampel pada Usaha mikro kecil menengah (UMKM) Tenun gedogan di Kota Bima, yaitu dengan menyebarkan kuesioner penelitian kepada para pelaku UMKM di kawasan Kota Bima. Responden yang mengisi kuesioner merupakan pemilik langsung (owner) dari UMKM tersebut.Produk UMKM tenun di Kota Bima tenun merupakan produk dengan prospek penjulan yang tinggi, melihat potensi tersebut kini para penenun dikelompokkan dan di data dengan baik. Kelompok atau sentra tenun di Kota Bima tersebar di delapan titik. Satu sentra membawahi sedikitnya 200 penenun 
tradisional. Dengan jumlah produksi satu penenun sekitar dua hingga empat kain dalam satu bulan.

\subsubsection{Karakteristik Responden Berdasarkan Umur}

Jumlah responden secara keseluruhan sebanyak 157 orang, dengan rincian jumlah responden menurut kelompok umur dapat dilihat pada Tabel berikut ini:

Tabel 4.1 Jumlah Responden Berdasarkan Kelompok Umur

\begin{tabular}{|c|c|c|c|}
\hline No & $\begin{array}{c}\text { Kelompok Umur } \\
\text { (Tahun) }\end{array}$ & $\begin{array}{c}\text { Jumlah } \\
\text { (Orang) }\end{array}$ & $\begin{array}{c}\text { Persentase } \\
\mathbf{( \% )}\end{array}$ \\
\hline 1 & $<20$ & 1 & 1 \\
\hline 2 & $21-25$ & 1 & 1 \\
\hline 3 & $26-30$ & 5 & 6 \\
\hline 4 & $31-35$ & 13 & 14 \\
\hline 5 & $36-40$ & 23 & 25 \\
\hline 6 & $41-45$ & 19 & 21 \\
\hline 7 & $46-50$ & 8 & 9 \\
\hline 8 & $51-55$ & 15 & 17 \\
\hline 9 & $56-60$ & 5 & 6 \\
\hline 10 & $61-65$ & 0 & 0 \\
\hline 11 & $66>$ & 0 & 0 \\
\hline & Total & $\mathbf{9 0}$ & $\mathbf{1 0 0}$ \\
\hline
\end{tabular}

Sumber : Data Primer Diolah 2019

Berdasarkan perhitungan terhadap karakteristik responden dalam Tabel 4.1terlihat sangat bervariasi dalam kelompok umur dan di dominasi oleh usia 36-40 tahun yang memberikan tanggapan terhadap keunggulan bersaing, hal ini menunjukan bahwa sebagian besar responden berada pada umur produktif dan berpotensi melakukan kegiatan tenun. Dimana tingkat kemauan pelaku usaha terhadap kegiatan tenun (UMKM) di Kota Bima.

\subsubsection{Karakteristik Responden Berdasarkan Tipe Usaha}

Dari hasil pengumpulan data primer berdasarkan tipe usaha responden adalah Ritel/Eceran, Jasa, Manufaktur dan lainnya. Secara lengkap distribusi responden menurut tipe usaha dapat dilihat pada Tabel 4.2berikut ini:

Tabel 4.2Jumlah Responden Berdasarkan Tipe Usaha

\begin{tabular}{|c|c|c|c|}
\hline No & TIPE USAHA & $\begin{array}{c}\text { Jumlah } \\
\text { (Orang) }\end{array}$ & $\begin{array}{c}\text { Persentase } \\
(\mathbf{9})\end{array}$ \\
\hline 1 & Ritel/Eceran & 85 & 94 \\
\hline 2 & Jasa & 0 & 0 \\
\hline 3 & Manufaktur & 0 & 0 \\
\hline 4 & Lainya & 5 & 6 \\
\hline \multicolumn{2}{|c|}{ Total } & $\mathbf{9 0}$ & $\mathbf{1 0 0}$ \\
\hline
\end{tabular}

Berdasarkan perhitungan terhadap karakteristik responden dalam Tabel 4.3 dimana ada beberapa tipe usaha yaitu Ritel/Eceran, Jasa, Manufaktur dan lainnya. Dilihat dari tangapan responden terkait tipe usaha.Jumlah responden yang dominasi dalam memberikan tanggapan sebanyak 85 responden yaitu tipe usaha Ritel/Eceran.

\subsection{Analisis Data}

\subsubsection{Hasil Uji Validitas}

Tabel . 4.3 Hasil Uji Validitas

\begin{tabular}{|c|c|c|c|c|}
\hline $\begin{array}{c}\text { r. Hitung } \\
\text { Variabel X1 }\end{array}$ & $\begin{array}{c}\text { r. Hitung } \\
\text { Variabel X2 }\end{array}$ & $\begin{array}{c}\text { r. Hitung } \\
\text { Variabel Y }\end{array}$ & r. Tabel & Keterangan \\
\hline$(\mathrm{X} 1.1) 0,772$ & $(\mathrm{X} 2.1) 0,585$ & $(\mathrm{Y} .1) 0,872$ & 0,300 & Valid \\
\hline$(\mathrm{X} 1.2) 0,798$ & $(\mathrm{X} 2.2) 0,584$ & $(\mathrm{Y} .2) 0,846$ & 0,300 & Valid \\
\hline
\end{tabular}




\begin{tabular}{|l|l|l|l|l|}
\hline$(\mathrm{X} 1.3) 0,693$ & $(\mathrm{X} 2.3) 0,816$ & $(\mathrm{Y} .3) 0,874$ & 0,300 & Valid \\
\hline$(\mathrm{X} 1.4) 0,657$ & $(\mathrm{X} 2.4) 0,906$ & $(\mathrm{Y} .4) 0,591$ & 0,300 & Valid \\
\hline (X1.5) 0,630 & $(\mathrm{X} 2.5) 0,912$ & $(\mathrm{Y} .5) 0,558$ & 0,300 & Valid \\
\hline (X1.6) 0,798 & $(\mathrm{X} 2.6) 0,643$ & $(\mathrm{Y} .6) 0,664$ & 0,300 & Valid \\
\hline
\end{tabular}

Sumber : Data Primer diolah 2019

Hasil pengujian validitas variabel Orientasi Pasar Dan Inovasi Produk Pengaruhnya Terhadap Keunggulan Bersaing Studi Pada UMKM Tenun Gedogan Kota Bimadapat dikatakan valid pada Corrected item-total correlation $>0,300$. Hasil pengujian validitas ini menunjukkan bahwa pernyataan kuesioner dalam penelitian ini valid.

\subsubsection{Hasil Uji Reliabilitas}

\begin{tabular}{|} 
Tabel. 4.4 Hasil Uji Reliabilitas \\
\begin{tabular}{|c|c|c|}
\hline Variabel & CronbachAlpha & Keterangan \\
\hline Orientasi Pasar (X1) & .818 & Reliabel \\
\hline Inovasi Produk (X2) & .839 & Reliabel \\
\hline Keunggulan Bersaing (Y) & .832 & Reliabel \\
\hline
\end{tabular}
\end{tabular}

Sumber : Data diolah 2019

Hasil Uji Relibialitas diatas menujukan bahwa item pertanyaan di tiga variabel memiliki nilaiCronbach alpha> 0,600.Dengan demikian butir soal tersebut dinyatakan konsisten atau reliable/stabil, sehingga dapat dipergunakan untuk penelitian.

\subsection{Uji Asumsi Klasik}

Uji Asumsi klasik dilakukan untuk memperoleh nilai penduga yang tidak bias dan efisien dari persamaan regresi dengan metode penafsiran kuadrat terkecil biasa (ordinary least square). Oleh karena itu, dalam pelaksanaan analisa data harus memenuhi asumsi klasik. Pengujian model regresi meliputi uji asumsi normalitas, multikoliniearitas, heteroksedasitas, dan autokorelasi. Uraian dari perhitungan pengujian asumsi model regresi dapat dijelaskan.

\subsubsection{Hasil Uji Normalitas}

Uji normalitas bertujuan untuk menguji apakah antara variabel dependen dan variabel independen memiliki distribusi data yang normal atau tidak. Pengujian normalitas data dalam penelitian ini menggunakan metode grafik dan uji Kolmogorof-Smirnov.

\section{Grafik PP-Plot Uji Asumsi Normalitas}

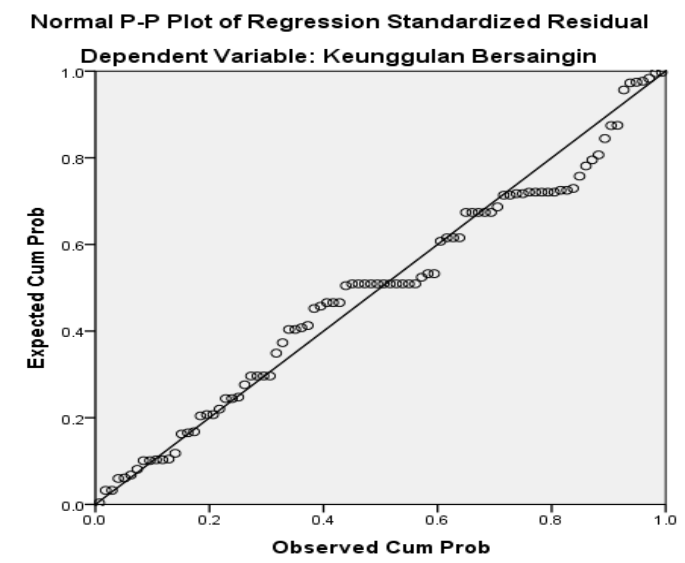

Penelitian ini menggunakan dua variabel independen, maka pengujian normalitas data terbagi menjadi Data dari plot sisaan regresi telah menyebar normal mendekati garis diagonal dan dilakukan uji mengunkan uji Kolmogorof-Smirnov dengan nilai signifikansinya lebih besar dari 0,05 (Irianto, dalam Aris : 2017). Hasil uji normalitas adalah sebagai berikut: 
Data kolmogorov-smirnov (KS)

One-Sample Kolmogorov-Smirnov Test

\begin{tabular}{|ll|l|}
\hline & & $\begin{array}{l}\text { Unstandardized } \\
\text { Residual }\end{array}$ \\
\hline N & & 90 \\
Normal Parametersa,b & Mean & $0 \mathrm{E}-7$ \\
& Std. Deviation & 1.63058070 \\
& Absolute & 113 \\
Most Extreme Differences & Positive & 113 \\
& Negative & -.074 \\
Kolmogorov-Smirnov $Z$ & & 1.070 \\
Asymp. Sig. (2-tailed) & & 203 \\
\hline
\end{tabular}

Hasil nilai Asym.Sig pada persamaan diatas diperoleh sebesar 0,203 hasil ini bila dibandiingkan dengan probabilitas 0,05 maka lebih besar, sehingga dapat disimpulkan bahwa data penelitian ini berdistribusi normal.

\subsubsection{Uji Multikolinearitas}

Untukmendeteksi ada tidaknya multikolinieritas dapat dilihat dari Variance Inflation Faktor (VIF). Apabila nilai VIF $>10$ maka menunjukkan adanya multikolinieritas. Apabila sebaliknya $\mathrm{VIF}<10$ maka tidak terjadi multikolinieritas. Pengujian asumsi multikolinier dapat dilihat pada tabel sebagai berikut:

Tabel. 4.5 Uji Asumsi Multikolinieritas

\begin{tabular}{|c|c|c|}
\hline Variabel Bebas & \multicolumn{2}{|c|}{ Sebelum Transformasi } \\
\cline { 2 - 3 } & VIF & Keterangan \\
\hline Orientasi Pasar (X1) & 2.370 & Tidak Multikolinier \\
\hline Inovasi Produk (X2) & 2.370 & Tidak Multikolinier \\
\hline
\end{tabular}

Sumber : Data diolah, 2019

Berdasrkan hasil perhitungan yang ada pada Tabel masing-masing variabel bebas menunjukkan nilai VIF Untuk Pengujian Multikolinearitas pada penelitian ini dapat disimpulkan bahwa masing-masing sesudah transformasi menunjukkan nilai VIF yang tidak lebih dari 10, maka tidak terjadi multikolinieritas

\subsubsection{Uji Heteroskedastisitas}

Pengujian asumsi heterokedastisitas dilakukan dengan melihat grafik plot. Indikasi terjadinya heterokedastisitas tampak pada pola tertentu yang dibentuk dalam plot. Apabila tidak terlihat adanya pola tertentu serta titik-titik penyebaran diatas dan dibawah sumbu $\mathrm{Y}=0$, maka tidak diindikasikan adanya heterokedastisitas.

\section{Uji Asumsi Heteroskedastisitas}

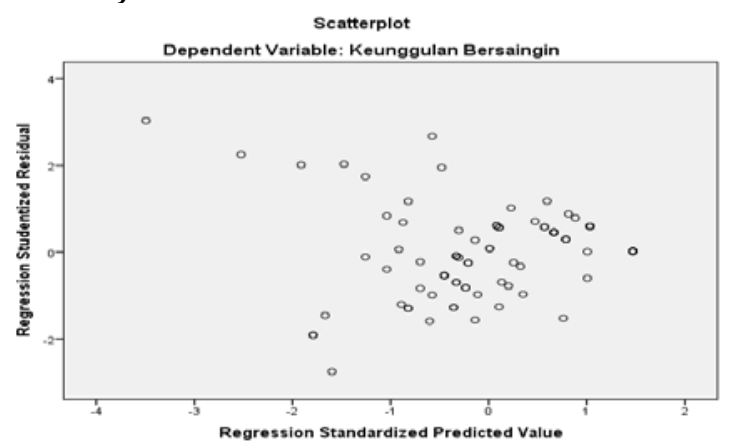


Berdasarkan Gambar plot diatas dapat dilihat bahwa titik-titik plot tidak membentuk pola tertentu dan cenderung menyebar disekitar sumbu $Y=0$. Oleh karena itu dapat disimpulkan tidak terjadi heteroskedastisitas.

\subsubsection{Uji Autokorelasi}

Pengujian ada tidaknya autokorelasi pada regresi variabel dependen dilakukan dengan memeriksa statistik Durbin- Watson (DW).

Tabel. 4.6 Hasil Uji Autokorelasi

\begin{tabular}{|c|c|c|c|c|}
\hline Durbin Watson & $\mathrm{dl}$ & $\mathrm{du}$ & $4-\mathrm{du}$ & Keterangan \\
\hline 2.056 & 1.6119 & 1.7026 & 2,2974 & Tidak Terdapat Autokorelasi \\
\hline
\end{tabular}

Sumber : Data Primer diolah, 2019

Nilai uji D-W berada di daerah tidak ada autokorelasi berdasarkan Hasil uji DurbinWatson menunjukan bahwa1.7026<2.056 <2, 2974. Dapat dilihat berdasarkan kriteria Jika $\mathrm{dU}<\mathrm{D}-\mathrm{W}<4-\mathrm{dU}$, kesimpulannya pada data tidak terdapat autokorelasi. Nilai uji D-W berada di daerah tidak ada autokorelasi, sehingga dapat disimpulkan bahwa persamaan regresi yang dihasilkan tidak terdapat gajala autokorelasi.

\subsection{Hasil Uji Hipotesis}

Selanjutnya untuk mengetahui apakah hipotesis yang diajukan dalam penelitian ini diterima atau ditolak maka akan dilakukan pengujian hipotesis dengan menggunakan uji t. Hasil pengujian hipotesis dijelaskan sebagai berikut:

Tabel. 4.7Coefficients ${ }^{\mathrm{a}}$

\begin{tabular}{|c|c|c|c|c|c|c|}
\hline \multirow{2}{*}{\multicolumn{2}{|c|}{ Model }} & \multicolumn{2}{|c|}{$\begin{array}{l}\text { Unstandardized } \\
\text { Coefficients }\end{array}$} & $\begin{array}{c}\text { Standardized } \\
\text { Coefficients }\end{array}$ & \multirow[t]{2}{*}{$\mathrm{t}$} & \multirow[t]{2}{*}{ Sig. } \\
\hline & & B & Std. Error & Beta & & \\
\hline \multirow{3}{*}{1} & (Constant) & 8.262 & 1.555 & & 5.315 & .000 \\
\hline & Orientasi Pasar & .260 & .087 & .300 & 2.986 & .004 \\
\hline & Inovasi Produk & .464 & .086 & .540 & 5.376 & .000 \\
\hline
\end{tabular}

Sumber : Data Primer Diolah, 2019

\subsubsection{Pengujian Hipotesis Pertama.}

Hasil statistik uji $t$ untuk variabel diperoleh nilai $t_{\text {hitung }}$ sebesar 2,986 dengan nilai $t_{\text {tabel }}$ sebesar 1,987 $(2,986>1,987)$ dengan nilai signifikansi sebesar 0,004 lebih kecil dari 0,05 $(0,004<0,05)$, yang artinya hipotesis menyatakan bahwa "Orientasi Pasar berpengaruh positif dansignifikanterhadap keunggulan bersaing". Apabila UMKM tenun gedogan ingin meningkatkan keunggulan bersaingmaka harus melakukan orientasi pasar yang merupakan budaya perusahaan secara mendasarmenetapkan prinsip perilaku perusahaan berkenaan dengan pelanggan, pesaing dan fungsi internal. Dengan orientasi pasar, UMKM dapat mengetahui, memahami serta menjawab kebutuhan maupun harapan dari pelanggan, serta dapat mengetahui kelemahan dankekuatan pesaing serta mengkoordinasian sumber dayaperusahaan sehingga akhirnyadapat meningkatkan keunggulan bersaing.

Orientasipasar memilikiprospek yang baik untuk lebih ditingkatkan dan dikembangkan sebagai pilihan strategi yang berhubungandengan penciptaan dan pemuasan pelangan dengan caraterusmenilai kebutuhan dan keingginan pelanggan. Penerapanorientasi pasarakanmembawa pada peningkatan keunggulan bersaing pada perusahaan tersebut.

Hasil penelitian ini konsisten dengan hasil penelitian sebelummnya yang dilakukan oleh Sensi Tribuana Dewi dalam jurnal Aris, (2017) memperoleh kesimpulan yang sama bahwa orientasi pasar berpengaruh positif dan signifikan terhadap keunggulan bersaing. 


\subsubsection{Pengujian Hipotesis Kedua.}

Hasil statistik uji $t$ untuk variabel diperoleh nilai $t_{\text {hitung }}$ sebesar 5,376 dengan nilai $t_{\text {tabel }}$ sebesar 1, $987(5,376>1,987)$ dengan nilai signifikansi sebesar 0,000 lebih kecil dari 0,05 $(0,000<0,05)$, yangartinya hipotesis menyatakan bahwa "Orientasi produkberpengaruh positif dan signifikanterhadap keunggulan bersaing". Hal ini karena inovasi produk adalah elemen utama yang berdampingan dengan orientasi pasar sebagai kunci utama keberhasilan produk untuk dapat diterima oleh konsumen agar dapat memenangkan persaingan. Hal ini berarti bahwa sangat relevan bagi para pengusaha Tenun Gedogan agar terus mengembangkan dan meningkatkan inovasi produk yang dapat menciptakan keunggulan bersaing produk tersebut.

Hasil penelitian ini sejalan dengan hasil penelitian yang dilakukan oleh Ikhsan Badruz zaman (2017)dengan yang menyatakan bahwa inovasi produk berpengaruh positif dan signifikan terhadap keunggulan bersaing.

\subsubsection{Pengujian Hipotesis Tiga.}

Uji F digunakan untukmengetahui apakahvariabelindependen secarabersama-sama (stimultan) memilikipengaruh signifikan baik positif maupun negatif terhadap variabel dependen. Hasil pengujian hipotesis dijelaskan sebagai berikut :

Tabel. 4.8ANOVA ${ }^{a}$

\begin{tabular}{|ll|l|l|l|l|l|}
\hline \multicolumn{1}{|c|}{ Model } & $\begin{array}{l}\text { Sum of } \\
\text { Squares }\end{array}$ & $\mathrm{df}$ & Mean Square & $\mathrm{F}$ & Sig. \\
\hline \multirow{2}{*}{1} & Regression & 401.190 & 2 & 200.595 & 73.750 & $.000^{\mathrm{b}}$ \\
& Residual & 236.633 & 87 & 2.720 & & \\
& Total & 637.822 & 89 & & & \\
\hline
\end{tabular}

Sumber : Data Primer Diolah 2019

Dari uji ANOVA atau $F$ test diperoleh $F$ hitungsebesar 73,750. Untuk menentukan $F_{\text {tabel }}$ digunakan lampiran statistika $F_{\text {tabel }}$ dengan menggunakan $\alpha=5 \%$. Nilai df1 (jumlah variabel -1 ) atau $3-1=2$ dan df2 (n-k-1) atau $90-2-1=87$. Maka diperoleh $F_{\text {tabel }}$ sebesar 3,10. Hal ini mengartikan bahwasanya nilai $F_{\text {hitung }}>F_{\text {tabel }}$ yaitu 73,750 $>3,10$ sehingga $\mathrm{H}_{0}$ di tolah dan $\mathrm{H}_{\mathrm{a}}$ diterima. Dari hasil tersebut diperoleh kesimpulan bahwa terdapat pengaruh positif dan signifikan orientasi pasar dan inovasi produk terdahap keunggulan besaing pada UMKMTenun di Kota Bima.

Keunggulan bersaing adalah kemampuan suatu badan usaha atau perusahaan untuk memberikan nilai lebih terhadap produknya dibandingkan dengan para pesaingnya dan nilai tersebut memang mendatangkan manfaat bagi pelanggan.

Penelitian ini konsisten dengan hasil penelitian Aristin Nikmah (2015) dalam Jurnalnya memperoleh hasil bahwa secara simultan orientasi pasar dan inovasi produk memiliki pengaruh yang positif dan signifikan terhadapkeunggulan bersaing. Hal ini menunjukan bahwa kedua faktor tersebut memliki dampak pada peningkatan kemampuan industri dalam menghadapi persaingan yang ada. Peningkatan orientasi pasar terutama dalam mengenal pelanggan dan pesaing serta penciptaan inovasi produk yang sesuai dan tepat sasaran sehingga semua hal tersebut akan dapat mempengaruhi keunggulan bersaing.

\subsubsection{Uji Koefisien Determinasi $\left(R^{2}\right)$}

KoefisienDeterminasi mengukurseberapabesarpengaruh variabelindependen terhadapvariabel dependen.Nilai koefisien determinasi menggunakan Nilai $R$ Square. Dan hasilnyadapatdilihatpadatabel 5.7 berikut: 


\section{Jurnal Magister Manajemen Unram Vol. 8, No 4. November 2019 NATIONALLY ACCREDITED JOURNAL - DECREE NO. 21/E/KPT/2018}

Tabel 4.9

Model Summaryb

\begin{tabular}{|c|c|c|c|c|}
\hline Model & $\mathrm{R}$ & R Square & $\begin{array}{c}\text { Adjusted R } \\
\text { Square }\end{array}$ & $\begin{array}{c}\text { Std. Error of the } \\
\text { Estimate }\end{array}$ \\
\hline 1 & $.793^{\mathrm{a}}$ & .629 & .620 & 1.64922 \\
\hline
\end{tabular}

Sumber : Data Primer Diolah 2019

Dari data diatas, dapat diketahui bahwa koefisien determinasi (Nilai R Square) yang diperoleh sebesar 0,629. Hal ini menunjukkan bahwa variabel orientasi pasar dan inovasi produk hanya mempengaruhi sebesar $62,9 \%$ terhadap keunggulan bersaing. Sedangkan sisanya $37,1 \%$ dipengaruhi oleh variabel lain yang tidak diteliti dalam penelitian ini.

\section{KESIMPULAN DAN SARAN}

Berdasarkan hasil analisis dan pembahasan dalam penelitian yang telah dilakukan terhadap pemilik dan pengelola UMKM Tenun Gedogan di Kota Bima maka kesimpulan yang didapat ialah sebagai berikut :

1. Orientasi pasar secara langsung berpengaruh positif dan signifikan terhadap keunggulan bersaing pada UMKM Tenun Gedogan di Kota Bima. Hal ini berarti bahwa sangat relevan bagi para pengusaha Tenun untuk selalu memperhatikan dan meningkatkan orientasi pasar agar menciptakan keunggulan bersaing yang berkesinambungan.

2. Inovasi produk secara langsung berpengaruh positif dan signifikan terhadap keunggulan bersaing pada UMKM Tenun Gedogan di Kota Bima. Hali ini karena inovasi produk adalah elemen utama yang berdampingan dengan orientasi pasar sebagai kunci utama keberhasilan produk untuk dapat diterima oleh konsumen agar dapat memenangkan persaingan. Hal ini berarti bahwa sangat relevan bagi para pengusaha Tenun agar terus mengembangkan dan meningkatkan inovasi produk yang dapat menciptakan keunggulan bersaing produk tersebut.

3. Orientasi Pasar dan Inovasi Produk memiliki pengaruh positif dan signifikan terhadap keunggulan bersaing. Hal ini menunjukkan bahwa ketiga faktor tersebut memiliki dampak pada peningkatan kemampuan Pengusaha dalam menghadapi persaingan yang ada. Apabila pembelajaran yang dilakukan oleh suatu usaha dilakukan dengan baik, peningkatan orientasi pasar terutama dalam mengenal pelanggan dan pesaing serta penciptaan inovasi produk yang sesuai dan tepat sasaran sehingga semua hal tersebut akan dapat mempengaruhi keunggulan bersaing.

4. UMKM Tenun perlu memperhatikan orientasi pasar terutama mengenai orientasi pelanggan, orientasi pesaing, dan informasi pasar untuk dapat meningkatkan keunggulan bersaing antar UMKM yang ada.

5. UMKM tenun perlu menigimplementasikan inovasi produk baik dalam bentuk kultur, tekhnik maupun administrasi untuk menciptakan keunggulan bersaing.

6. Dalam penelitian ini, Inovasi Produk memiliki pengaruh yang lebih tinggi dibandingkan Orientasi Pasar, namun untuk menciptakan keunggulan kompetitif yang maksimal maka UMKM harus mengkombinasikan kedua komponen ini.

7. Bagi peneliti selanjutnya, diharapkan dapat mengembangkan dan memperluas ruanglingkup penelitian ini, dengan menambah variabel independen lain yang belum terdapat dalampenelitian ini misalnya orientasi pesaing, desain produk, jalur distribusi produk. 


\section{DAFTAR KEPUSTAKAAN}

Adelina Agnes Lapian. (2016). Pengaruh Orientasi Pasar dan INOVASI Prosuk Terhadap Kinerja Pemasaran Pasa PT. BPR Prisma Dana Amurang.

Assauri, Sofjan. 2012. Manajemen Pemasaran. Jakarta: Rajawali. Gramedia Pustaka Utama

Cynthia Vanessa Djodjobo dan Hendra N. Tawas.2014. Pengaruh Orientasi Kewirausahaan, Inovasi Produk, dan keunggulan Bersaing Terhadap Kinerja Pemasaran Usaha Nasi Kuning di Kota Manado. Vol.2 No.3 September 2014

Ekawati, N. W., Rahyuda, I. K., Yasa, K. N. N., dan Sukaatmadja, I. P. G. 2016. Implementation of Ecoprenership and Green Innovation in Building Competitive Advantage to Generate Success of New Spa Products in Bali. International Bussiness Management, 10(14): 2660-2669.

Emory, C., and Coper, D. R. 2000. Business Reseaech Methods, Home Wood Irwin. Ensley, M.D., Carland, L.C, Carland, J. W., and Bank, M (1999). Exploring the Existence of Entrepreneural Team. International Journal of Management 16, 276-286

Ghozali, Imam. 2016. Aplikasi Analisis Multivariete Dengan Program IBM SPSS 23 (Edisi 8). Cetakan ke VIII. Semarang : Badan Penerbit Universitas Diponegoro.

Hair et al. (2010). Multivariate Data Analysis, Seventh Edition. Pearson Prentice Hall

Ikhsan Badruz Zaman, (2017), Engaruh Orientasi Pasar Dan Inovasi Produk Terhadap Keunggulan Bersaing (Studi Kasus Pada Produk Umkm Spd Speedometer Yogyakarta)

Jayaningrum, B Sanawiri (2018). pengaruh orientasi pasar, inovasi, orientasi kewirausahaan terhadap keunggulan bersaing dan kinerja pemasaran (studi pada kuliner kafe kota malang)

Kotler,Philip and Gary Armstrong. 2012. Prinsip-prinsipPemasaran. Edisi 13. Jilid 1. Jakarta: Erlangga.

Nikmah, Aristin. 2015. Pengaruh Orientasi Pasar dan Inovasi Produk Terhadap Keunggulan Bersaing IKM (sentra IKM Tenun Ikat Troso Kabupaten Jepara)

Pramesti, N. M V., dan Giantari, I. G. A. K. 2016. Peran Orientasi Pasar Memediasi Pengaruh Orientasi Kewirausahaan Terhadap Kinerja UKM Industri Kerajinan Endek. E-Jurnal Manajemen Unud. 5(9): 5754-5782

Putro Styo Aris, (2017), Analisis Pengaruh Orientasi Pasar Dan Inovasi Produkuntuk Meningkatkan Kinerja Pemasaran Pada Kampungbatik Laweyan Solo.

Robbins, Stephen P. dan Coulter, Mary. (2010). Manajemen (edisi kesepuluh). Jakarta: Erlangga.

Saiman,L. 2014. Kewirausahaan (Teori, Praktik, dan Kasus-kasus), edisi kedua. Salemba Empat, Jakarta.

Sugiyono. (2016). Metode Penelitian Kuantitatif Kualitataif dan Kombinasi (Mixed Methods).Bandung: Alfabeta.

Susanto Parengki (2012). Pengaruh Advertising Terhadap Pembentukan Brand Awareness Serta Dampaknya Pada Keputusan Pembelian Produk KecapPedas Abc (Studi Kasus Pada Konsumen Pengguna Kecap Pedas Abc DiKota Semarang. 